\title{
रणहार उपन्यासमा ऐतिहासिकता
}

\author{
विष्णु न्यौपाने, पिएच.डी *
}

\section{लेखसार}

प्रस्तुत लेखमा 'रणहार' उपन्यासमा ऐतिहासिकतासम्बन्धी विमर्श गरिएको छ। ऐतिहासिक उपन्यासलेखन सत्ताइतिहासको वर्णन गर्दे वि.स. $95 ९ ०$ तिर 'त्रिरत्नसौन्दर्यगाथा' हुँदै टुकराज पद्मराज मिश्रका 'रजबन्धकी' (9९९६) र 'रामकष्ण कुँवर राणा' (9९९९) बाट आरम्भ भएको हो। त्यसपछि डायमनशमशेर राणाका वसन्ती (२००६), सेतो बाघ (२०३०) हुँदै विकसित भएको नेपाली ऐतिहासिक उपन्यास लेखन परम्परा वि. सं. २०७४ सालमा प्रकाशित 'रणहार' उपन्याससम्म आइपुगदा निकै समृद्ध र परिपक्क हुनपुगोको छ। 'रणहार' उपन्यास ऐतिहासिक उपन्यास श्रृड्खलाको एक महत्वपूर्ण कृति बन्न पुगोको छ । यस उपन्यासमा प्रस्तुत कथानक, कथावस्तुमा संलग्न रहेका सहभागीहरू र कथावस्तुका घटनाहरू घटेका स्थान, काल र वातावरण इतिहास संवद्ध छन्। पृथ्वीनारायण शाहको विशाल नेपालको परिकल्पनाअनुरूप नेपाल एकीकरणको अभियानमा गोरखाली फौजले भक्तपुर आक्रमणको तयारी र त्यसमा प्राप्त गरेको सफलताको विषय नै यस उपन्यासको मूल कथ्य हो । प्रस्तुत कृतिपरक अनुसन्धानमूलक लेखमा यस उपन्यासका ऐतिहासिक तथ्यहरूलाई कृतिगत साक्ष्यका आधारमा विषयको विवेचना गरिएको छ। गुणात्मक अनुसन्धानमा ढाँचामा आधारित प्रस्तुत लेखमा पुस्तकालय अध्ययनकार्यका आधारमा प्राथमिक र द्वितीयक स्रोतसामग्री सड़कलन गरी यिनैको अध्ययन, पुनरावलोकन, विश्लेषण गरी निष्कर्षीकरण गरिएको छ। यस उपन्यासमा प्रस्तुत ऐतिहासिकता सम्बन्धित पक्षहरूको मात्र विवेचना गरिनु यस लेखको सीमा हो। प्रस्तुत कृतिले इतिहास प्रसिद्ध विषयवस्तु, इतिहास प्रसिद्ध पात्र र ऐतिहासिक परिवेश (देश, काल र वातावरण) प्रस्तुत गरेको छ। उपन्यासमा प्रस्तुत कथावस्तु, पात्र र परिवेशमार्फत उपन्यासलाई ऐतिहासिक उपन्यासका रूपमा दय्याउनु प्रस्तुत लेखको निष्कर्ष रहेको छ।

शब्दकुन्जी : इतिहाससम्मत, ऐतिहासिक तथ्य, ऐतिहासिक यथार्थ, पूर्वदीप्ति, शीर्षकीकरण।

\section{विषयपरिचय}

इतिहास विगतमा भएका घटनाहरूको सत्यतथ्य विवरण हो भने उपन्यास जीवन र जगत्को कलात्मक प्रस्तुतीकरण हो। इतिहासले प्रायः सत्ताकेन्द्रित राजनीतिक विषयको जानकारी गराउँछ भने उपन्यास सत्ताभन्दा बाहिर समाजसम्म पनि पुगेको हुन्छ। इतिहासमा घटना घटेको तिथिमिति, ठाउँ र विषयको उल्लेख गरिएको हुन्छ। उपन्यास लेखनका विविध विषयहरूमध्ये इतिहास पनि एक विषय हुन सक्दछ। इतिहासलाई विषयवस्तुका रूपमा प्रस्तुत गरिएको उपन्यासलाई ऐतिहासिक उपन्यास भनिन्छ। ऐतिहासिक उपन्यासमा विगतमा भएका घटनाहरूको कलात्मक प्रस्तुतीकरण गरिएको हुन्छ। त्यस्ता उपन्यासमा घटना मात्र ऐतिहासिक भएर हुँदैन पात्र र परिवेश पनि इतिहाससम्मत हुनुपछ। नेपाली उपन्यास परम्परामा इतिहासलाई आधार बनाएर लेखिएका उपन्यासहरूमध्ये 'रणहार' पनि एक हो ।

\footnotetext{
* उपप्राध्यापक, सरस्वती बहुमुखी क्याम्पस (मानविकी सङ्काय, नेपाली विभाग), त्रिभुवन विश्वविद्यालय, नेपाल ।
} 
पथ्वीनारायण शाहले नेपाल एकीकरण अभियान आरम्भ गर्दा नेपाल विभिन्न ससाना राज्यहरूमा विभाजित थियो। तीमध्ये काठमाडौं उपत्यकामा तीन राज्यहरू : काठमाडौं (कान्तिपुर), ललितपुर (पाटन) र भक्तपुर (भादगाउँ) थिए। तीमध्ये ललितपुर प्रतिरोधबिनै गोरखालीहरूले आफ्नो हात पारेका थिए। त्यहाँका अन्तिम मल्ल राजा तेजनरसिंह मल्ल थिए। यिनी ललितपुर छाडी शरण लिन भक्तपुर पुगेका थिए। काठमाडौंमा इन्द्रजात्रा मनाइरहेका बेला अचानक गोरखाली फौजले आक्रमण गरी आफ्नो हात पारेका थिए। त्यहाँका अन्तिम राजा जयप्रकाश मल्ल थिए । यिनी पनि काठमाडौं छाडी शरण लिन भक्तपुर नै पुगेका थिए । उपत्यकाका मल्लवंशका तीन अन्तिम राजाहरू : काठमाडौंका जयप्रकाश मल्ल, ललितपुरका तेजनरसिंह मल्ल र भक्तपुरका रणजित मल्ल भक्तपुरको राजकूलको भण्डारखालमा जम्मा भएर बसेको समयमा गोरखाली फौजले भिंगटीका छाना छानाबाट आक्रमण गरेका थिए । त्यही भक्तपुर आक्रमणको घटना, गोरखाली फौजले भक्तपुर विजय गरेको घटना, रणजितको बाल्यकालीन जीवनको चित्रण, भूपतीन्द्रको शासनकाल तथा न्यातपोल मन्दिर निर्माणको प्रसड़ग नै 'रणहार' उपन्यासको मूल विषयवस्तु हो । यस उपन्यासमा नेपालको मल्लकालीन इतिहास, भक्तपुर दरबारको अवस्थिति, कलात्मक पक्ष र मल्लकालीन राजकीय प्रवृत्तिको यथार्थ तथा कलात्मक वर्णन गरिएको छ। भक्तपुर राज्यको राजकाजसम्बन्धी कुराहरू, नेवारी संस्कार र संस्कृति उपन्यासमा प्रस्तुत गरिएको छ। यस लेखमा 'रणहार' उपन्यासलाई ऐतिहासिक उपन्यास मानिने आधारहरूमा उपन्यासमा प्रस्तुत कथानक, पात्र र परिवेशको विश्लेषण गरिएको छ। उपन्यासको नामकरणमै ऐतिहासिकता तथा सामाजिक तथा सांस्कृतिक पक्षमा ऐतिहासिकता रहेको छ।

\section{अध्ययनको समस्या}

'रणहार' उपन्यासलाई ऐतिहासिक उपन्यास मानिने आधारहरू केके हुन् ? यस उपन्यासमा प्रस्तुत कथानक, पात्र र परिवेश केकस्ता रहेका छन् ? भन्ने प्राज्ञिक समस्याको अनुसन्धानमा नै यो लेख केन्द्रित रहेको छ।

\section{अध्ययनको उद्देश्य}

उपन्यासलाई ऐतिहासिक उपन्यास मानिने आधारहरू प्रस्तुत गर्दे विवेच्य उपन्यासमा प्रस्तुत गरिएको कथावस्तु, पात्र र परिवेशको अध्ययन र विश्लेषण गरी यस उपन्यासको ऐतिहासिकता विश्लेषण गर्नु नै यस लेखको उद्देश्य हो ।

\section{अध्ययनको औचित्य}

यस लेखमा उपन्यासलाई ऐतिहासिक उपन्यास मानिने आधारहरू प्रस्तुत गर्दे 'रणहार' उपन्यासमा प्रस्तुत गरिएको कथावस्तु, पात्र र परिवेश अध्ययन र विश्लेषण गरी यस उपन्यासको ऐतिहासिकता विश्लेषण गरिएको छ। यसबाट साहित्यका सर्जक, पाठक, समालोचक तथा अनुसन्धाताहरूसमेत लाभान्वित हुने भएकाले प्राजिक दृष्टिले यो अनुसन्धानात्मक लेख औचित्यपूर्ण रहेको छ। 


\section{अध्ययनको सीमा}

प्रस्तुत लेखमा उपन्यासलाई ऐतिहासिक उपन्यास मानिने आधारहरू प्रस्तुत गरी 'रणहार' उपन्यासमा प्रस्तुत कथावस्तु, पात्र र परिवेशको अध्ययन र विश्लेषण गर्नु यस लेखको सीमा हो ।

\section{अध्ययनविधि}

यस लेखमा अध्ययन विधिअन्तर्गत सामग्री सड्कलन कार्य र विश्लेषणको ढाँचालाई निम्नानुसार प्रयोगमा ल्याइएको छ।

\section{सामग्री सङ्कलन कार्य}

प्रस्तुत अनुसन्धानात्मक लेख पुस्तकालयीय अध्ययनका आधारमा प्राथमिक र द्वितीयक स्रोतहरूबाट अभिलेखीय साम्रगीहरू सड्कलन गरिएको छ। प्राथमिक स्रोतअन्तर्गत योगेश राजद्वारा लिखित 'रणहार' उपन्यास रहेको छ। द्वितीयक स्रोतअन्तर्गत उपन्यास सिद्धान्त, ऐतिहासिक उपन्याससम्बन्वी पूर्वअध्ययन, पुस्तक, पत्रपत्रिका, समीक्षात्मक तथा अनुसन्धानात्मक लेखरचनाहरू रहेका छन् । सामग्रीहरूको सङ्कलनमा केवल पुस्तकालयीय सामग्रीसङ्कलन विधिको प्रयोग गरिएको छ र पुस्तकालयीय सामग्रीसङ्कलनका स्रोत त्रिभुवन विश्वविद्यालयको केन्द्रीय पुस्तकालय एवम् आफ्नै व्यक्तिगत सड्ग्रहका पुस्तकहरू रहेका छन्।

\section{विश्लेषणको ढाँचा}

गुणात्मक अनुसन्धान ढाँचामा आधारित यस अध्ययनमा सोद्देश्यमूलक विधिका आधारमा सड्कलित अभिलेखहरूको वर्गीकरण, अध्ययन, व्याख्या र विश्लेषणबाट निचोडमा पुगिएको छ। उपन्यासको विश्लेषण ऐतिहासिकता मापनका आधारहरू : कथानक, पात्र र परिवेश तथा शीर्षकीकरण र सामाजिक सांस्कृतिक पक्षको सघन पाठविश्लेषणको पद्धति अँगालिएको छ। विषयको पुष्ट्याइंका निम्ति आगमनात्मक तर्कपद्धति अपनाइएको छ। शोधसमस्याको प्राज्ञिक र वस्तुनिष्ठ रूपले यस लेखमा समाधान गरिएको छ।

\section{सैद्धान्तिक पर्याधार}

इतिहास विगतमा भएका घटनाहरूको विवरण हो भने ऐतिहासिक उपन्यास विगतमा भएका घटनाहरूको कलात्मक प्रस्तुतीकरण हो। कुनै पनि विषय इतिहास हुनलाई त्यस विषयमा ऐतिहासिक तथ्य हुनुपई। ऐतिहासिक तथ्य भन्नाले इतिहासलाई पुष्टि गर्ने सामग्रीहरू हुन्। ऐतिहासिक सामग्रीअन्तर्गत कुनै पनि विषयवस्तु, त्यस विषयवस्तु घटाउने व्यक्ति, त्यो विषयवस्तु घटेको ठाउँ अनि मिति पर्दछन्। इतिहास र साहित्यबिच घनिष्ट सम्बन्ध रहेको हुन्छ। विगतमा घटेका घटना (इतिहास) नै आजका साहित्य हुन्। साहित्य सिर्जनाका विभिन्न स्रोतहरू : सामाजिक, पौराणिक, इतिहास वा कल्पनामध्ये इतिहास पनि एक हो। इतिहास साहित्यको जन्मदाता पनि मानिन्छ। प्राचीन साहित्यका विषयहरू प्राय: इतिहास हुन्थे। जीवनीमूलक साहित्यको विषय पनि इतिहास नै हुन्छ। साहित्यमा कल्पना र तथ्यको प्रस्तुति हुने भए पनि ऐतिहासिक साहित्यमा तथ्यको तोडमोड हुने तथा कल्पना प्रस्तुत गर्ने कुरा प्रायः त्याज्य मानिन्छन्। 
विगतको कुनै समयविन्दु जसमा मानव जीवनको विकास वा विनाससँग सम्बन्धित थियो त्यो समयविन्दुको घटना नै इतिहास हो। नेपाली बृहत् शब्दकोशमा "इतिहास अतीतकाल वा विगत समयका घटनाहरूको वर्णन, विश्लेषण र मूल्याड्कन गर्ने ज्ञानको एक शाखा, अतीतको अनुसन्धान र छानबिनमा आधारित अध्ययन, तत्सम्बन्धी ग्रन्थ भनिएको छ" (पोखरेल र अन्य, २०६७, पृ. ११६)। विगतका सबै समय महत्वपूर्ण हुँदैनन्। जुन समयमा जुन घटना घट्यो त्यतिबेला त्यो नै महत्वपूर्ण हुन्छ, त्यही विषय नै लेखिन्छ अनि त्यही नै इतिहास बन्न पुग्छ। त्यही घटनाको समयविन्दुमध्ये कुनै समयको घटनाको तथ्य नै इतिहास हो भने त्यही घटनालाई साहित्यिकता, कलात्मकता जोडेर प्रस्तुत गरियो भने त्यो साहित्य हुन्छ। इतिहासमा कल्पना जोडिदियो भने ऐतिहासिक साहित्य बन्न पुग्छ। साहित्यका विभिन्न विधाहरूमध्ये आख्यान विधा ऐतिहासिक तथ्य महत्वपूर्ण विषय बन्न सक्छ। "सफल ऐतिहासिक उपन्यासमा इतिहास र उपन्यास दुवैको विशेषता निहित हुनुपईः" (तिवारी, २०१५, पृ. ७)। उपन्यासमा ऐतिहासिकताको मापन कथावस्तु, पात्र र परिवेशका आधारमा हुन्छ। ऐतिहासिक उपन्यास हुन कथावस्तु, पात्र र परिवेश ऐतिहासिक हुनु आवश्यक हुन्छ। उपन्यासको भाषाशैली कलात्मक तथा प्रस्तुतिमा साहित्यिकता हुनैपई। ऐतिहासिक उपन्यासमा कल्पना हुनै नहुने भन्ने चाहिँ होइन। लोकमनोरज्जनार्थ तथ्यलाई नबड्ग्याई, तोडमोड नगरी केही काल्पनिकता पनि प्रस्तुत गर्न सकिन्छ। ऐतिहासिक उपन्यासको काल्पनिकतालाई साहित्यिक कला मान्न सकिन्छ। इतिहासको तथ्यपूर्ण, निराश र कठोरपनालाई कल्पनाले सुन्दर, श्रुतिमधुर, कुतूहल बनाउन सहयोग गर्दछ। अतिकाल्पनिक, जासुसी, तिलस्मी, ऐयारी प्रवृत्ति ऐतिहासिक उपन्यासमा हुनुहुँदैन। इन्द्रबहादुर राईका अनुसार इतिहासमा नाम र सालबाहेक अरू सबै भुटा हुन्छन् भने उपन्यासमा नाम र समय छोडेर बाँकी सब सत्य हुन्छन् (राई, २०५६, पृ. ९७)। उपन्यासमा घटनाको उल्लेख र वर्णन, पात्रको चरित्राङ्कन, स्थान, समय र वातावरणको गहन चित्रण र विश्लेषण गरिएको हुनुपई्छ। पात्रको नामकरण, पात्रविधान इतिहाससम्मत हुनुपछ। चरित्राङ्कनमा केही काल्पनिकता अपनाउन सकिन्छ। कुनै काल्पनिक पात्र र उसका केही कार्य काल्पनिक हुन पनि सक्दछन् तर प्रमुख पात्र काल्पनिक हुँदा ऐतिहासिकता ओकेलमा पर्न सक्दछ। स्थान र समय इतिहाससंवद्ध हुनुपर्दछ भने वातावरण पनि इतिहाससंवद्ध हुनैपर्दछ त्यसमा केही कल्पना पनि प्रस्तुत गर्न सकिन्छ। स्थान र समयको विवरण तथा वातावरणको गहन तथा सूक्ष्म विश्लेषण भएको हुनुपर्दछ। इतिहासका तत्वहरूअन्तर्गत सत्यतथ्य घटना, व्यक्ति, स्थान र समय पर्दछन्। ऐतिहासिक उपन्यासमा यी तीन कुराको समन्वय र समन्विति हुनुपर्दछ।

कोचेले समग्र इतिहास समसामयिक इतिहास हुन्छ, इतिहास भन्नु विगतको वर्तमान पुनःनिर्माण मात्र हो, एउटा काल्पनिक पुनर्जीवित मानेको बताएका छन्। इतिहास भनेको आफू जीवित रहेको वर्तमानमा आयात गरेर पुनर्निर्माण गरिएको विगत हो (राई, २०५६, पृ. ९७)। इतिहास सत्यतथ्य नहुन सक्छ किनभने यो शक्ति र सत्ताको आधारमा तयार पारिन्छ। ऐतिहासिक उपन्यास लेखिनुको मूल कारण सत्यतथ्यको प्रकटीकरण गर्नु हो। यो शक्ति र सत्ताभन्दा पनि मनशान्ति र लोकहितका लागि लेखिने भएकाले बढी आधिकारिक हुन सक्छ तर सबै ऐतिहासिक उपन्यास इतिहासको दस्तावेज नहुन पनि सक्छ। "ऐतिहासिक उपन्यास इतिहाससित सम्बन्धित हुन्छ, चाहे त्यो इतिहाससम्मत यथार्थ होस, चाहे ऐतिहासिक कालको कुनै व्यक्ति विशेषलाई प्रमुख पात्रको रूपमा प्रतिस्थापित गरेर अथवा तत्कालीन वातावरणलाई स्थान दिएर स्वतन्त्र रूपमा लेखिएको होस्, सबैलाई ऐतिहासिक उपन्यासको संज्ञा दिने गरिन्छ” (प्रधान, २०४२, पृ. 
१२६-१२७)। टीकाराम पोखरेल ऐतिहासिक उपन्यास सम्बन्वमा भन्दछन्, "ऐतिहासिक उपन्यास औपन्यासिक कला र इतिहासबिचको सम्कौता हो। इतिहासले उपन्याससमक्ष आत्मसमर्पण गरेमा ऐतिहासिकता मर्दछ भने उपन्यासले इतिहाससमक्ष आत्मसमर्पण गरेमा उपन्यास पलायन हुन्छः" (२०६६, पृ. ७२)। अड्ग्रेजी साहित्यमा ऐतिहासिक उपन्यासका जनक सर वाल्टर स्कटलाई मानिन्छ। त्यस्तै चार्ल्स डिकिन्स, लियो टाल्स्टाय, मार्गरेट मिचेल अड्ग्रेजी साहित्यका ऐतिहासिक उपन्यासकार हुन्। नेपाली साहित्यमा पनि ऐतिहासिक विषयलाई आधार बनाएर उपन्यासहरू लेखिएका छन्। तीमध्ये योगेश राजद्वारा लिखित 'रणहार' पनि एक हो ।

\section{कथानक}

'रणहार' उपन्यासमा पथथ्वीनारायण शाहको नेपाल एकीकरणको ऋममा भक्तपुर विजय गर्दाको प्रसड़ग आएको छ। पब्लिकेसन नेपालयले प्रकाशन गरेको, डिमाइ आकारको एक सय बाउन्न पृष्ठमा फिँजारिएको विषयवस्तु उन्नाइस खण्डमा विभाजित छ। उपन्यासका उन्नाइस खण्डमध्ये खण्ड एक पर्वदीप्ति फ्ल्यासब्याक) शैलीमा आएको छ जसमा गोरखाली फौजले ललितपुर आफ्नो कब्जामा लिई इन्द्रजात्रा मनाउँदाको दिन कान्तिपुर विजय गरी तीनै सहरका राजाहरू भक्तपुर दरबारमा जम्मा भई बसेका बेला आक्रमण गरी विजय गर्दाको विषय आएको छ। त्यसैको निरन्तरतामा अठ्ठार र उन्नाइस खण्ड गोरखालीले भक्तपुर जितेपछिको यिनीहरूको व्यवस्थापनको विषयवस्तु आएको छ। रणजितको हार भएपछि, गोरखाली फौजले यिनलाई नजरबन्धमा नराखी बरु सम्मानका साथ कुनै एक गाउँको राजा भएर बस्न सल्लाह दिएका छन्। पचहत्तर वर्षे वृद्ध रणजित हार स्वीकार नगरी स्वाभिमानी भएर बरु काशीवास जाने विचार व्यक्त गरेका छन्। खण्ड दुईदेखि पाँचसम्मका घटनाहरू रणजितको नौ वर्ष आसपासको उमेरका छन्। खण्ड छ देखि आठ भपतीन्द्रको शासन काल र न्यातपोत मन्दिर बनाउँदाको प्रसड़ग आएको छ। खण्ड नौदेखि सत्रसम्मका घटनाहरू रणजितको जन्मदेखि पाँच-छ वर्षको उमेरका गतिविधि, बुबा भूपतीन्द्रको देहावसान, रणजितको राज्यारोहण, राजकाजसम्बन्धी विषयहरू आएका छन् । युद्धमा रणजितको हार भएपछि गोरखाली फौजले यिनलाई नजरबन्धमा नराखी बरु सम्मानका साथ कुनै एक गाउँको राजा भएर बस्न सल्लाह दिएका छन् तर पचहत्तर वर्षे वृद्ध रणजित हार स्वीकार नगरी स्वाभिमानी भएर बरु काशीवास जाने विचार व्यक्त गरेका छन् । रणजितको वरिपरि उपन्यासको विषयवस्तु फैलिएको छ।

भक्तपुर दरबार सुन्दर कलाले भरिएको थियो। यीमध्ये भैरव चोक सबभन्दा सुन्दर थियो। चोकको चारैतिर सुनौला रङ पोतिएका थिए। दलानमा तीनतिर लहरै अठार भैरव उभिएका थिए। यहाँ अठार मुद्रा देखाउँदै, अठार जातिका पशुपक्षी चढेका थिए, अठार भाव पोख्ने अठार रङका थिए । माथि भ्याल भ्यालमा समेत विचित्रका आकृति थिए। भ्यागुतोले सिंहको चुल्ठो समातेर ख्याल गरेका, हात्तीलाई भ्यागुतोले निल्न लागदा कागले हात्तीलाई जिस्क्याइरहेका जस्ता अनौठा दृश्य थिए। यस चोकमा मृत्युशोक थुप्प्रेको हुन्थ्यो। राजपरिवारका सदस्यले अन्तिम सास यही चोकमा फेर्दथे। मरणासन्न व्यक्ति र मृत्यु आशङ्काले कहालिएका मानिस यहाँ राखिन्थे। सदाशिव र भैरवचोक जोडिएको थियो। राजा नरेश मल्लले अठार भैरवको मूर्ति स्थापना गरेका थिए। 
कान्तिपुरमा महामारी फैलिएको हुन्छ। दिनहुँ डेढ सय मानिस मरिरहेका हुन्छन्। महामारी फैलनुमा ज्योतिषीले मलमास परेको समयमा कान्तिपुरले दसैं मनाएकाले जगदम्बा उग्र भई महामारी लिएको, बौद्ध श्रद्धालुले चाकबहाद्य: बसेको रथ आगो लागेकाले यो उपद्रव भएको पो हो कि भन्ने धारण राख्दछन् । वास्तवमा असमयमा भीषण वर्षा भएर चोक चोकमा निकै दिनसम्म पानी जमेको, यही पानीमा मरेका मुसा, बिराला, सुँगुर, कुकुर सडेकाले महामारी फैलिएको थियो। त्यसै महामारीको शान्तिको लागि स्वयम्भूमा शान्तिहोम गरिएको हुन्छ।

राजा भूपतीन्द्रले भक्तपुरको पाँचतले (न्यातपोल) मन्दिर बनाउन लगाउँछन्। यस मन्दिरलाई चाहिने काठ एक सय अठ्ठाइस जनाले एक महिनासम्म कटेका, दुई हजार चार सय जति मोहीले चालिस लाख इँट पोल्ने काममा लागेका थिए। एक सय चालिस धार्नी फलामलाई दुई सय तिस भारी गोल बालेर गालिएको, तेलिया इँट मात्रै एक लाख र भाले कुखुरा र चरा देखिने छ हजार इँट बनाइएको थियो। कुनै एक दिन रात तेस्रो प्रहरमा पुगदा राजाले सपना देख्छन्। यही सपनाको शुभअशुभ बारे चर्चा हुन्छ। नेपाल संवत् आठ सय तेइसमा बालक जन्मन्छन्। राजदरबारमा उत्सव मनाइन्छ। मूलचोकमा दीपावली गरिन्छ। भोलिपल्ट नगरभरका मानिसलाई मासु र मिठाई बाडेर युवराज जन्मेकामा हर्षोल्लास मनाइन्छ।

रणजित पाँच नाघेर छ वर्षमा लागदा भूपतीन्द्रको देहावसान हुन्छ। यतिबेला पूरै भक्तपुर शोकमय भएको हुन्छ। दस दिनसम्म दरबार चकमन्न रहन्छ, मूलचोकमा आरती चल्दैन, नौदफा बज्दैन, नाचगान हुँदैन, उत्सव मनाइदैन। तेह्रौं दिन होम सकेपछि विश्वभर उपाध्याजुले रणजितलाई जीवन र मरण बारे केही कुरा बताउँछन्। भूपतीन्द्रको मृत्युशोकमा राजा भएका हुनाले रणजितलाई मृत्युशोक लागैै। अर्को वर्ष राजमाताको देहावसान हुन्छ।

रणजित राजा हुन्छन्। कान्तिपुरको राजबैठकले वाभू आक्रमणका लागि सैनिक पठाउने निर्णय गर्दछ। सैनिकको नेतृत्व काजी भागल ठाकुरले गर्दछ्न्। अवध नवाबका दूत भएर कासिखान कान्तिपुर उक्लेका हुन्छन्। कासिखानलाई काजी बनाएपछि हिन्दु र मुसलमान बिच काटमार चल्न थाल्छ। नेपाल संवत् दू० श्रावण शुक्लपुर्णिमाका दिन कान्तिपुरका काजी कागलको नेतृत्वमा कान्तिपुर, ललितपुर र गोर्खाको संयुक्त फौजले वाभू जित्दछ्। । मुसलमानहरू रातारात चोभार काटी भागदछ्।

गाईजात्रा पर्व मनाइदै हुन्छ। मुसलधारे पानी परेको हुन्छ। उन्नाइस वर्षे राजा रणजित विभिन्न वासनात्मक कृत्यमा रमाउन थाल्छन्। गाईजात्राको काँकीमा हिड्दै गरेकी एउटी तरुनी तर उदास अनुहार देखेर यिनी लोभिन्छन्। यिनले चार, पाँच दिनसम्म त्यही अनुहार सम्किरहन्छन्। उनी राजकाजमा व्यस्त हुन्छन्, शस्त्रअस्त्र चलाउने अभ्यासमा लागदछ्। यिनले काजी यज्ञनारायण प्रधानाड्गसँग राज्यकोषबारे सल्लाह लिने, तवधिकसँग बाटोघाटो, पुल, पाटी, पोखरी, मन्दिर बनाउने सल्लाह लिने, जिजु महारानीसँग पुराना पुराना कुरा सुन्ने गर्दथे।

केही महिनादेखि भोटका लामासँग टक चल्तीफिर्तीलाई लिएर खटपट सुरु हुन्छ। पुरानो महिन्द्रमल्ली खिइएको र राजा भूपतीन्द्र मल्लको नाउँ टड्केका मुद्रा खोटो निस्केको कुरा ल्हासामा भोटेहरूले उठाएका थिए। भोटे व्यापारीसित लेनदेन गर्न हिच्किचाउँदै थिए। यता रणजित कार्यबोधले शारीरिक र मानसिक 
रूपमा कमजोर हुँदै थिए। रणजित र मनमैंजुबिच भलाकुसारी हुन्छ। गाईजात्राको राती मनमैंजुलाई पनि एक जोर युवा आँखाले सुम्सुम्याए जस्तो लागेको थियो। राजाले आफूसित विवाह गर्न चाहेको कुरा मनमैंजुले भरखरै थाहा पाएकी थिइन्। मनमैंजुले पानि रणजितलाई प्रेम गर्न थालेकी थिइन्। रातभर रणजित र मनमैंजु मानसिक र शारीरिक वासनात्मक प्रेममा लिन भएका थिए।

रणजितले क्रिस्चियन पादरीहरूलाई गिर्जाघर बनाउन घर किनिदिएका, धर्मप्रचार गर्न छुट दिएका थिए। यसले गर्दा गोरखाली भारदारहरूको एउटा तप्का राजासँग चिढिएका थिए। यिनीहरू रणजितको राजकाजबाट आजित भएर गोरखालीहरूलाई मन पराउन थालिसकेका थिए। यस्तो अवस्थामा गोरखालीहरूले भक्तपुरलाई चारैतिरबाट आक्रमण गर्दछ्। यिनीहरूले चौकोट दरबारमा आगो लगाइदिन्छन्। मल्लवंशका तीन अन्तिम मल्ल राजाहरू, भक्तपुरे राजकुमारहरू, बुढाकाजी भागीराम, राजखजाज्चि, चार जना काजी, रणजितका आठपहरिया, गरुडनारायण आदि भक्तपुरको राजकुलको भण्डारखालमा जम्मा भएका थिए। पृथ्वीनारायण शाहको नेतृत्वमा भएको नेपाल एकीकरणको ऋममा भक्तपुरका मल्लफौज र गोरखाली फौजको अन्तिम युद्ध भक्तपुरमा चलिरहेको थियो। गोरखाली फौजले तीनै राजाहरूसहित यी सबैलाई बन्धक बनाई भक्तपुर विजय गरेको घोषणा गर्दछन्। तेजनरसिंह मल्ल बोल्न नसक्ने अवस्थामा पुगेका हुन्छन्। जयप्रकाश मल्ल भय्याङ उक्लिन लागदा गोरखाली फौजले हानेको गोली लागी रक्ताम्मे हुन्छन्। रणजितले आत्मसमर्पण गर्दछन्। यिनले आत्मसमर्पण गरिसकेपछि, दुभाजुकहाँबाट भत्केको पर्खाल हुँदै मूलचोकमा ल्याई राखिन्छ। यिनी पचहत्तर वर्षका हुन्छन्। गोरखाली राजाले बनेपा, पनौती, साँखु, थिमी, बोडे, कीर्तिपुरमध्ये कुनै एक गाउँ लिएर राजा भएर बस्नु आम्दानी पुच्याइदिउला भन्दा यिनी बरु काशी जाने विचार व्यक्त गर्दछ्। गोरखाली फौजले भक्तपुर जिती कव्जामा लिए पनि कुनै लुटपाट, आगजनी तथा कसैलाई नेल ठोक्ने जस्ता दु:ख दिने काम भने गरेका थिएनन्।

\section{पात्र}

'रणहार' उपन्यासको विषयवस्तु भक्तपुर दरबार र गोरखा दरबारसँग सम्बन्धित भएकाले यिनै दुई दरबारसँग सम्बन्धित पात्रहरू नै उपन्यासमा प्रयुक्त छन्। रणजित यस उपन्यासका प्रमुख पात्र हुन्। जयप्रकाश मल्ल, तेजनरसिंह मल्ल, भूपतीन्द्र मल्ल, विश्वलक्ष्मी, लालमती, मनमैंजु, विश्वम्भर उपाध्याय, राजज्योतिषी, राजवैद्य, बुढाकाजी भागीराम, प्रधानाड्ग काजी, प्रधानकाजी, काजी धनओंत, काजी यज्ञनारायण प्रधानाङ्ग आदि पात्रहरू पनि रहेका छन्।

\section{रणजित मल्ल}

रणजित मल्ल भक्तपुर राज्यका अन्तिम मल्ल राजा हुन्। उपन्यासमा यिनी राजकुमार, युवराज, राजा भूपतीन्द्र मल्लका छोरा, जुजुचाका नामद्वारा सम्बोधित छन्। राजपरिवारमा जन्मेकाले यिनको बाल्यकाल 
सुखद रहेको थियो। यिनका वरिपरि सुसारेहरू हुन्थे। यिनीहरूलाई प्रश्न सोहने यिनी जिज्ञासु स्वभावका थिए। यिनले धेरै उट्पट्याङ कार्यहरू गर्थे। "सबै चन्चल बालकभै" रणजित असीम ऊर्जाका पुज्ज थिए, अनि बेजोडका डुलुवा पनि। उनको रखवारी गर्नेहरू कायल हुन्थे। एक पलक यताउति भयो भने युवराज बिलाउँथे" (राज, २०७६, पृ. १२)। युवराज भएकाले यिनलाई सबै काम गर्न छुट थियो। बिना रोकतोक जे पनि गर्न पाउने भएकाले कुनै बेला मर्यादाभन्दा पर पनि पुगेका हुन्थे। यिनका वरिपरि यिनको हेरचाहमा खटिएकाहरू हत्तुहराम भएका हुन्थे।

\section{भूपतीन्द्र मल्ल}

भूपतीन्द्र मल्ल रणजितका पिता हुन्। यिनलाई उपन्यासमा जिजुबुबा सुमति राजा, भूपति जुजु आदि नामद्वारा सम्बोधन गरिएको छ। यिनी विकासप्रेमी राजा थिए। यिनले भक्तपुरमा पाँचतले भव्य मन्दिर बनाउन लगाएका थिए। यस कार्यमा यिनी आफैं पनि खटेर लागेका थिए। यो मन्दिर बनाउन ठुलो जन र धनको खर्च भएको थियो। "यस मन्दिरलाई चाहिने काठ काट्न थिमीका चालिस, बनेपाका आठ, खम्पुका आठ, भक्तपुरका बाह, पनौतीका सत्र, नालाका सोह्ह, साँगाका तेह, धुलिखेलका चौधजनाले भन्डै एक महिनासम्म रुख काटेका काट्यै थिए" (राज, २०७६, पृ. पूर)। यो मन्दिर यिनको प्रतिष्ठासँग जोडिएको यिनले महसुस गरेका थिए। यसै मन्दिरको निर्माणपश्चात् नियमित पूजापाठमा पनि यिनले ध्यान दिएका थिए।

\section{जयप्रकाश मल्ल}

जयप्रकाश मल्ल काठमाडौंका अन्तिम मल्ल राजा हुन्। गोरखाली फौजले कान्तिपुरमाथि हमला गरी जितिसकेपछि यिनी भक्तपुर रणजितकहाँ शरण लिन पुगेका थिए। तीनै जना जम्मा भई बसेको ठाउँमा गोरखाली फौजले आक्रमण गर्दा यिनी घाइते भएका थिए। यिनी भच्याङ उक्लिन लागदा गोरखाली फौजले हानेको गोली लागी रक्ताम्मे भएका थिए।

\section{गोरखाली फौज}

गोरखाली फौज वीर र साहसी देखिन्छन् । यिनीहरू नेपाल एकीकरणको अभियानमा भक्तपुर आक्रमण र विजयको घटना यस उपन्यासमा आएको छ। यिनीहरू, "अभिमानले रन्केका, तन्नेरी अनुहार, तामा र गहुँ मिसिएको वर्ण, चौडाललाट, बाक्ला बाक्ला आँखीभौं, कैला नानी, गालाका कसिला छाला, पातलो जुँगाको रेखा, भुठ बोल्न नजान्ने, बान्की नपरेका ओठ, निर्भीक, अनुदार चित्तका थिए” (राज, २०७६, पृ. ६)।

\section{अन्य पात्र}

'रणहार' उपन्यासमा उल्लिखित पात्रबाहेक अन्य पात्र पनि प्रयुक्त छन्। विश्वम्भर उपाध्याय, भैरव मल्लवीर जोशी, काजी कागल ठाकुर, मनमैंजु, तेजनरसिंह मल्ल (पाटनका अन्तिम मल्ल राजा), विश्वलक्ष्मी ( 
आमारानी), लालमती (जिजुमुमा, राजमाता), राजज्योतिषी, राजवैद्य, बुढाकाजी भागीराम, प्रधानाङ्ग काजी, प्रधानकाजी, काजी धनओंत सिं, काजी यज्ञनारायण प्रधानाड्ग (राज्यकोषको आम्दानीखर्चबारे सुभाव दिने व्यक्ति), गरुडनारायण (राणजितका अड्गरक्षक, रणजितका चार वर्षदेखिका टहलुवा, बफादार चाकर), जोशिनी बज्यै, भागीराम (जेठा चौतारा), तवधिक (भागिरामका छोरा, रणजितको बाटोघाटो, पुल पाटी, पोखरी, मन्दिर बनाउने अनुभव सुनाउने व्यक्ति), कागल ठाकुर, काजी खान (नवाबका दूत, काजी), केशरसिं चित्रकार, मसिनुचा (धाईआमा, सुसारे), कुमारी माजु, जमुना थकुं, राजखजान्ची, भाजुकस: हेमनारां, केहरसिं बस्त्यात आदि रहेका छन्। सदाशिव मल्ल (बाजेका बाजे), भक्तपुरे राजकुमारहरू, चार जना काजी, भागिरामकी बिधवा बहिनी, भास्कर मल्ल (स्वर्गवासी राजा), पृथ्वीनारायण, भजनमण्डली, सुसारे आमा, अमात्य, दुवाकोटका द्वारे, दही भण्डारी, जोशिनी बज्य, बुहारी, राजगीर, तवधिक, रामचन्द्र, दुर्गा मल्लवीर जोशी, जयधर्म, चामल भण्डारी, चाकु भण्डारी, घ्यू भण्डारी (बेतिया बेहुली लिन हिँडेकाहरू), भरियाहरू, खर्पनेहरू, राजगुरु, रणजितका आठपहरिया, धनलक्ष्मी (रणजितकी सुसारे), ज्यापुनी, टहलुवाहरू जस्ता पात्र उपन्यासमा प्रयुक्त छन् ।

\section{परिवेश}

'रणहार' उपन्यासमा भक्तपुर दरबार र यस आसपासको क्षेत्र परिवेशका रूपमा आएका छन् । भक्तपुरको राजकुलको भण्डारखालको भ्यालको कलात्मक वर्णन यसरी गरिएको छ, "भक्तपुर दरबारमा विभिन्न चोक गरी उनान्सय चोक थिए। चोक, चोकैपिच्छे इनार, ढुड़्रेधारा र जलद्रोणी थिए। यिनै मूलचोक, भण्डारखालचोक, सिद्धिचोक, हिटिचोक, गणेशचोक आदि थिए। दरबारको हृदयस्थलमा मूलचोक थियो। मूलचोकको दक्षिण लडमा तलेजुमाता विराजमान थिइन" (राज, २०७४, पृ. ११)। उपन्यासमा चाँगुनारायण मन्दिरपरिसर वरपरको सुन्दर वातावरणको चित्रण गरिएको छ। काठमाडौंका स्वयम्भू र वसन्तपुरसम्मको परिवेश उपन्यासमा आएका छन्। उपन्यासमा वाग्मती नदी र पशुपति आसपासको वातावरणको चित्रण यसरी गरिएको छ। वि.सं. १६२५ आसपासको समय यस उपन्यासको कालगत परिवेश हो । रणजितको जन्म, छ, नौ, उन्नाइस र पचहत्तर वर्षे उमेरका विशेष घटनाहरू उपन्यासमा आएका छन्। लगभग पचहत्तर वर्षभन्दा बढीको समयावधि उपन्यासमा प्रयुक्त छ। भूपतीन्द्रको शासन कालको केही सन्दर्भ तथा न्यातपोल निर्माणको प्रसड्ग पनि उपन्यासमा आएका छन् ।

\section{नामकरणमा ऐतिहासिकता}

उपन्यासको नामकरण विभिन्न आधारमा गर्न सकिन्छ। रचयिता, विषयवस्तु, नायक, नायिका वा अन्य कुनै पात्रका आधारमा उपन्यासको नामकरण गर्न सकिन्छ। नामकरणमै चरित्रको महत्वपूर्ण भूमिका रहेको हुन्छ। विश्वनाथले नाटकका सन्दर्भमा नायक नायिकाका आधारमा नामकरण गरिनुपर्ने धारणा राखेका छन् २०२३, पृ. १४६)। जर्ज वाट्सनले पनि उपन्यासको नामकरण नायक नायिकाको नामका आधारमा गर्न सकिने धारणा राखेका छन् (सन् १९७९, प्. ५३३-५४)। नेपाली साहित्यमा पनि पात्रलाई आधार बनाएर उपन्यासको नामकरण भएका छन् : 'सुमति' (विष्णुचरण श्रेष्ठ), 'रूपमती' (रुद्रराज पाण्डे), 'मङ्गली' (इन्द्र सुन्दास), 'अनुराधा' (विजय मल्ल), 'नरेन्द्रदाइ' (विश्वेश्वरप्रसाद कोइराला), 'आशमाया' (डि. पि. अधिकारी), 'माधवी' (मदनमणि दीक्षित) आदि। उपन्यासको नामकरण पात्रका आधारमा गरिएको पाइन्छ जसको विशेष 
अर्थ पनि रहेको हुन्छ। यस्तै 'रणहार' उपन्यास भक्तपुरका राजा रणजितको गोरखाली फौजसँग रणमा हार भएको विषयवस्तु प्रस्तुत गरिएको छ। यो उपन्यासको नामकरण 'रणहार' उपन्यासका प्रमुख पात्र रणजितका आधारमा राखिएको छ। रणजित पात्रको रणमा हार भएको प्रसड्ग उपन्यासमा आएको छ। नाम जित भए पनि यिनको यथार्थमा चाहिँ हार भएको देखाइएको छ। त्यसैले उपन्यासको शीर्षक प्रतीकात्मकरूपमा सार्थक र विषयका रूपमा ऐतिहासिक रहेको छ।

\section{सामाजिक तथा सांस्कृतिक पक्षमा ऐतिहासिकता}

'रणहार' उपन्यासमा मल्लकालीन उपत्यकाको ऐतिहासिक सामाजिक पक्षको यथार्थ चित्रण गरिएको छ। कान्तिपुरमा महामारी फैलिएर दिनहुँ डेढ सय मानिस मरिरहेका थिए । यो महामारी फैलनुमा विभिन्न धारणाहरू व्यक्त गरिएका थिए, "मलमास परेको समयमा कान्तिपुरले दसैं मनाएकाले जगदम्बा उग्र भई महामारी लिएको कुरा ज्योतिषीले बताएका थिए। देउपाटनका बिसेतहरूले पशुपतिको अघोरमुखको दारा निस्कदै गरेको देखेका थिए । बौद्ध श्रद्धालुले चाकबहाद्य: वसेको रथ आगो लागेकाले यो उपद्रव भएको, हनुमानढोकाको सिंहासनमा केही महापातकी चढेका हुन् कि वा अधर्मले धुरीबाट कराएको पो हो कि पनि भन्थे" (राज, २०७६, पृ. ४४-४५) । देवीदेवता रिसाएका जस्ता यी धारणा आए पनि वास्तवमा असमयमा भीषण वर्षा भएर चोक चोकमा निकै दिनसम्म पानी जमेको, यही पानीमा मरेका मुसा, बिराला, सुँगुर, कुकुर सडेकाले महामारी फैलिएको थियो। महामारीको शान्तिको लागि स्वयम्भूमा शान्तिहोम गरिएको थियो ।

उपन्यासमा राजाले देखेको सपना उल्लेख गरिएको छ। "मसान भैरव रक्तपात्रबाट रगत पिउँदै थिए । रगतले मात्तिदै थिए । पहिरेका मुण्डमाला छिनाल्दै हुयाउँदै थिए। एउटा एउटा खप्पर परसम्म वेगले उड्थ्यो। अन्तरिक्षमा ग्रह उपग्रहजस्तै। फेरि कहाँ कतै साह्रो सतहमा ठोकिन्थ्यो। चर्ण हुन्थ्यो। गिदीका पहैँला छिटा फ्यात्त पर्थे। उनी ती सब हेरिरहेका थिए। तर त्यो कहाँ अथवा किन हुँदै थियो भन्ने जान्न अयोग्य थिए। सुनौला साँकको बेला थियो। कतै नजिकै नदी बगदै थियो। पृष्ठभूमिमा बाजाको ताल बज्दै थियो (राज, २०७४, पृ. ६४) । यस सपनाले राजा र रानीका मनमा सन्ताप पैदा हुन्छ। यो मृत्युको पूर्वसड्केत थियो। यो सपना देखेको केही समयपछि राजको देहावसान भएको थियो। रणजित पाँच नाघेर छ वर्षमा लागदा जिजुबुबा सुमतिराज भूपतीन्द्रको देहावसान हुन्छ। 'रणहार' उपन्यासमा मल्लकालीन संस्कार र संस्कृति जनाउने निम्न प्रसड्ग आएका छन्, "खेतिपाती गर्ने बेला खनजोत गर्दा कीरा, फट्याड्ग्रा र भ्यागुता मारिएका होलान् भनी तिनको मृत्युदोष निवारणका लागि ज्यापुनीहरू भ्यागुतोलाई भोज खुवाएर आइपुगेका थिए” (राज, २०७६, पृ. १००)। गाईजात्रा मनाएको सन्दर्भ पनि उपन्यासमा आएको छ।

\section{निष्कर्ष}

उपन्यासकार योगेश राजद्वारा लिखित 'रणहार' उपन्यासमा नेपालको मल्लकालीन इतिहास, भक्तपुर दरबारको अवस्थिति, कलात्मक पक्ष, राजकीय प्रवृत्तिको यथार्थ तथा कलात्मक वर्णन उल्लेख गरिएको छ। मल्लकालीन नेवारी संस्कार र संस्कृतिको जगेर्ना गर्नु र त्यसको ऐतिहासिक यथार्थ जानकारी गराउनु यस उपन्यासको मूल उद्देश्य रहेको बुक्किन्छ। उपन्यासमा काठमाडौं उपन्यकाका अन्तिम मल्ल राजाहरूको अवसान तथा गोरखाली फौजको भक्तपुर विजय अभियान मूल घटना प्रस्तुत गरिएको छ। उपन्यासमा 
प्रयुक्त रणजित, जयप्रकाश जस्ता ऐतिहासिक पात्रहरू रहेका छन् । काठमाडौं वरिपरिको काठमाडौं उपत्यसका विजय गर्दाको समयको परिवेश उपन्यासमा चित्रित छन् । काठमाडौ उपत्यकाका नेवारी समुदायका सामाजिक, सांस्कृतिक दिनचर्या र मल्ल राजाहरूको राजकीय परम्परा, मृत्युसंस्कार उपन्यासमा आएका छन् । उपन्यासको नामकरण पनि प्रमुख ऐतिहासिक पात्र रणजितकै आधारमा राखिएको छ। भूपतीन्द्र मल्लको राजकाज र भक्तपुरको पाँचतले मन्दिर बनाउँदाको लगाब पनि उपन्यासमा आएको छ। भक्तपुर दरबार क्षेत्रका कलात्मक सुन्दर पक्षहरूको पनि उपन्यासमा चित्रण गरिएको छ। प्रस्तुत उपन्यासमा ऐतिहासिक घटना, ऐतिहासिक पात्रहरू र ऐतिहासिक परिवेश साक्ष्यका रूपमा रहेको बुभिन्छ। यसर्थ यो नेपाली ऐतिहासिक उपन्यास हो ।

\section{सन्दर्भ सामग्रीसूची}

तिवारी, गोपीनाथ (२०१५), ऐतिहासिक उपन्यास और उपन्यासकार, आगरा : साहित्य रत्न भण्डार। पोखरेल, बालकृष्ण र अन्य (सम्पा.), (२०६७), नेपाली बृहत् शब्दकोश (सा.सं.), काठमाडौं : नेपाल प्रज्ञा प्रतिष्ठान ।

पोखेल, भोलानाथ (२०६६), आधुनिक नेपाली सामाजिक यथार्थवादी उपन्यासको पात्रविधान, विद्यावारिधि शोधप्रबन्ध, काठमाडौं : त्रिभुवन विश्वविद्यालय।

प्रधान, कृष्णचन्द्रसिंह (२०४२), नेपाली उपन्यास र उपन्यासकार (ते.सं.), ललितपुर : साभा प्रकाशन।

राई, इन्द्रबहादुर (२०४६), नेपाली उपन्यासका आधारहरू (ते.सं), ललितपुर : साभा प्रकाशन।

राज, योगेश (२०७६), रणहार (दो.सं.), काठमाडौं : पब्लिकेसन नेपालय ।

विश्वनाथ, साहित्यदर्पण (अनु. ), (२०२३), कोमलनाथ अधिकारी, काठमाडौं : नेपाल प्रज्ञा प्रतिष्ठान ।

Watson, George (1979), The Story of the Novel, London : The Makmilon Press. 